\title{
Assessment of chlorophyll-a, chlorophyll-b and growth rate in freshwater green algae Pseudokirchneriella subcapitata exposed to cadmium and copper
}

\author{
Agnè Čypaitè, Jūrate Žaltauskaitè, Jonè Venclovienė \\ Vytautas Magnus University, Vileikos st. 8-223, Kaunas LT-44404, Lithuania
}

\begin{abstract}
In this work, the effect on green algae Pseudokirchneriella subcapitata exposed to different concentrations of cadmium and copper was evaluated through growth rate and the chlorophyll- $a$, chlorophyll- $b$ concentrations. The algae were exposed for 7 days to five different cadmium and copper concentration ranging from 1 to $1000 \mu \mathrm{g} / \mathrm{l}$. Data show that cadmium was more toxic to Pseudokirchneriella subcapitata growth than copper, all treatments of cadmium inhibited Pseudokirchneriella subcapitata growth unlike copper, of which only the highest concentration tested $(1000$ and $100 \mu \mathrm{g} \mathrm{Cu} / \mathrm{l})$ inhibited the growth of algae cells. Regression analysis revealed that growth rate of Pseudokirchneriella subcapitata significantly decreased with increasing concentration of metals ions $\left(\mathrm{Cd}-\mathrm{R}^{2}=0.7, p<0.001\right.$; $\mathrm{Cu}-\mathrm{R}^{2}=0.99, p<0.001$. Cadmium and copper had the significant adverse effect on the chlorophyll- $a$ and chlorophyll- $b$ concentrations of P.subcapitata cells (chlorophyll- $a$ ANOVA, $\mathrm{Cd}: \mathrm{F}=10.8, p<0.001 ; \mathrm{Cu}: \mathrm{F}=8.1 p<0.001$, chlorophyll- $b$ ANOVA, Cd: $\mathrm{F}=10.16$, $p<0.001 ; \mathrm{Cu}: \mathrm{F}=10.06, p<0.001)$. The results showed that chlorophyll- $a$ and chlorophyll- $b$ concentration were less sensitive to metals than the growth rate.
\end{abstract}

Keywords: toxicity; water quality; cadmium; cupper; Pseudokirchneriella subcapitata.

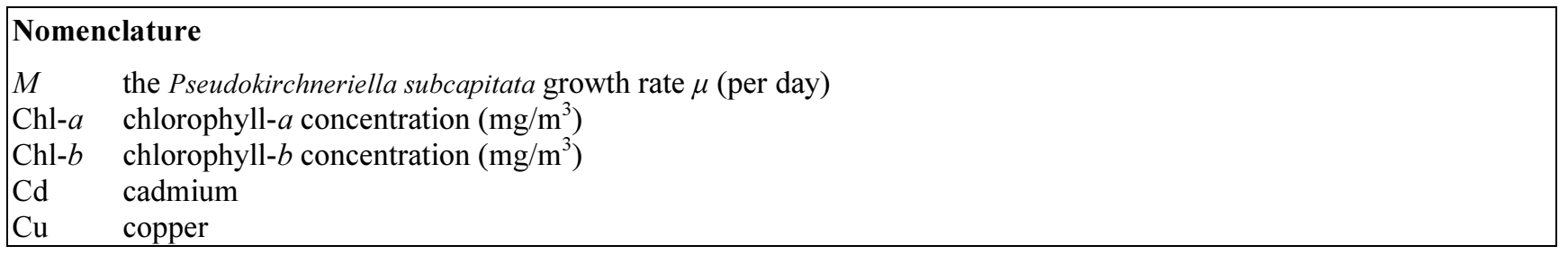

\section{Introduction}

Pollution of the biosphere with heavy metals has become a serious concern in the whole world. The release of these metals in the environment has dramatically increased as a result of anthropogenic activities. Metals enter surface waters from a variety of sources including industrial discharges, domestic sewage, nonpoint runoff, urban storm runoff and atmospheric deposition. The relevant feature that distinguishes trace metals from other toxic pollutants is that they are nonbiodegradable, having high environmental persistence [1]. Heavy metals entering the aquatic ecosystems may cause algae growth disorders [2-3], inhibit floating and rooted plant growth [4-5], disturb the process of photosynthesis [6], induce oxidative stress, various physiological changes [7-9], cause potential mutagenic effects [10], inhibit reproduction of plants and animals and reduce their survival [11-12]. However it is often hard to detect the subtle and non-lethal effects of lowlevel metal exposure in aquatic systems [13]. All non-essential heavy metals, as well as essential ones when present in higher concentrations than optimal, affect different cellular components thereby interfering with the normal metabolic functions of plant cell [14]. Abiotic factors such as $\mathrm{pH}$, watter hardness, salinity, dissolved organic substances can affect the concentration of the free metal ion, which is generally considered to be the most bioavailable and toxic form. on the other hand, the same factors also affect the binding of the metal ion to the biotic ligands, which is a prerequisite for an adverse effect. Therefore, the abiotic factors may exert different effects on the toxicity of metals in different organisms [15].

Corresponding author: Agné Čypaitė. E-mail address: a.cypaite $@ g m f . v d u .1 t$

http://dx.doi.org/10.3846/enviro.2014.009

(C) 2014 The Authors. Published by VGTU Press. This is an open-access article distributed under the terms of the Creative Commons Attribution License, which permits unrestricted use, distribution, and reproduction in any medium, provided the original author and source are credited. 
Cadmium $(\mathrm{Cd})$ is a non-essential metal toxic to aquatic organisms in the range of several micrograms per litter. Cadmium is a widely distributed metal, which has considerable technological relevance (pigments, anti-corrosive, polymer-additive, batteries), and which may be present in coal and phosphate minerals. It binds to organic molecules by forming bonds with sulphur and nitrogen, thereby inactivating proteins and is therefore capable of causing a broad range of adverse effects. It is easily absorbed and bio-accumulated by lower organisms and transferred to higher tropic levels in food chain [13]. Due to its relative high volatility, it is released with the flue gases of coal-fired power plants by which it is widely distributed and diffusely deposited. In the aquatic environment, it is mobile under toxic conditions but is retained in anoxic sediments [16]. Cadmium cause cellular toxicity via several pathways, e.g., nonspecifically binding to physiologically important proteins, substituting essential metals in metalloenzymes, or interfering with DNA repair and membrane lipid peroxidations [17]. Cd toxicity is known to be induced by the generation of reactive oxygen species, it was shown that e when algal cells (Chlamydomonas reinhardtii) are exposed to a higher $\mathrm{Cd}$ concentration a higher percentage of the algae population is expected to show the intracellular generation of reactive oxygen species [18].

Copper is a trace element essential for all living organisms, which acts as a structural element in regulatory proteins, and participates in electron transport in photosynthesis, mitochondrial respiration, oxidative stress responses, cell wall metabolism and hormone signalling [19-21]. Toxicity of copper is mainly due to the existence of two readily interconvertible oxidation states making it highly reactive, and it can catalyse the formation of free radicals through HaberWeiss reaction [22].

The use of algae in water quality assessment is common practice [23-25]. The use of algae bioassays has numerous advantages, such as, ease of culture, use of simple inorganic culture media and rapid growth rate [26]. Another major advance has been the miniaturization of the tests, i.e. the use of microliter volumes of samples in microplates as opposed to milliliter volumes of samples in flasks, so as to enable the easy and rapid processing of multiple samples [27-29].

The aim of the study was to analyse the chronic impact of $\mathrm{Cd}$ and $\mathrm{Cu}$, as the representatives of the non-essential and essential heavy metals, on the growth of Pseudokirchneriella subcapitata and to determine their effects on the content of photosynthetic pigments (chlorophyll- $a$, chlorophyll- $b$ ).

\section{Materials and methods}

Algal growth inhibition tests were performed according to the modified OECD guidelines 201 for the testing of chemicals [30] with the green algae Pseudokirchneriella subcapitata (formerly known as Selenastrum capricornutum). Pseudokirchneriella subcapitata were cultured in ISO 8692:2004 [31] standard medium. The culture flasks were supplied with various concentrations of $\mathrm{Cd}$ and $\mathrm{Cu}$ with a range of $1-1000 \mu \mathrm{g} / \mathrm{l}$. The concentrations of both metals were $1,2,10,100$ and $1000 \mu \mathrm{g} / \mathrm{l}$ with three replicates for each concentration. The metals used for this study were supplied as $\mathrm{CdCl}_{2}$ and $\mathrm{CuCl}_{2}$. Algal cells were treated with metals for 7 days.

Axenic cultures were started with an inoculation density of $5 \times 10^{3}$ cells $/ \mathrm{ml}$ and were illuminated continuously with fluorescent tubes at an intensity of $60-120 \mu \mathrm{mol} / \mathrm{m}^{2} * \mathrm{~s}$; the temperature was $23 \pm 2{ }^{\circ} \mathrm{C}$. All tests were conducted in three replicates in $250 \mathrm{~mL}$ Erlenmeyer flasks with ground necks containing $100 \mathrm{ml}$ of medium, the medium was aerated and shaken by hand every day. All glassware was washed with half-conc. $\mathrm{HNO}_{3}$ and rinsed thoroughly with deionised water, finally with bidistilled water. All media and glassware were autoclaved before use.

Algal concentration growth was measured daily by direct cell counting using a microscope and a counting chamber. The growth rate $\mu$ (per day) was calculated as follows [23]:

$$
\mu=\left(\ln N_{t}-\ln N_{0}\right) / t_{n}
$$

with $N_{t}$ the final cell density (cells $\left.\mathrm{ml} / \mathrm{l}\right), N_{0}$ the initial cell density (cell $\mathrm{ml} / \mathrm{l}$ ) and $t_{n}$ the time (day) after the initiation of the test. The $\mathrm{EC}_{50}$ (the effect concentrations that reduces algae growth or chl- $a$ /chl- $b$ concentration by $50 \%$ ) values were calculated based on the percentage inhibition of the growth rate compared to the control [32]. Effective concentration ( $\left.\mathrm{EC}_{50}\right)$ values were calculated using a logistic dose-response model. Biomass of algae was assessed as cell number in the medium.

The percent inhibition of growth rate for each treatment replicate calculated from the equation:

$$
\% I=\left(\mu_{\mathrm{C}}-\mu_{\mathrm{T}}\right) / \mu_{\mathrm{C}}
$$

where $\%$ I percent inhibition in average specific growth rate; $\mu_{\mathrm{c}}$ mean value for $\mu$ in the control; $\mu_{\mathrm{T}}$ value for growth rate in the treatment.

Photosynthetic pigment measurement was carried out on the last day of each experiment. Content of chlorophylls (a, $b$ ) was measured spectrofotometrically in $100 \%$ acetone extract [33]. The absorbance of the solution was determined at 750 , 664, 647 and $630 \mathrm{~nm}$. The concentration of chlorophyll a and b in the extract calculated by inserting the 1-cm OD664, OD647, OD630 in Jeffrey and Humphrey formulae:

$$
\begin{aligned}
& \mathrm{Chl} \mathrm{a}, \mathrm{mg} / \mathrm{l}=11.85(\mathrm{OD} 664)-1.54(\mathrm{OD} 647)-0.08(\mathrm{OD} 630) \\
& \mathrm{Chl} \mathrm{b}, \mathrm{mg} / \mathrm{l}=21.03(\mathrm{OD} 647)-5.43(\mathrm{OD} 664)-2.66(\mathrm{OD} 630)
\end{aligned}
$$

Chlorophyll- $a$ and chlorophyll- $b$ concentrations were calculated through equation: 


$$
\operatorname{mg} \operatorname{Chl}(-a ;-b) \mathrm{m}^{3}=\mathrm{Ca} \times \mathrm{E} / \mathrm{G}
$$

where $\mathrm{Ca}$ - chlorophyll $(-a ;-b)$ concentration in the extract $(\mathrm{mg} / \mathrm{l}) ; \mathrm{E}$ - extract volumes, $\mathrm{l} ; \mathrm{G}-$ grab sample volume, $\mathrm{m}^{3}$.

Statistical analysis. The statistical analysis was performed using the program Statistica 7.A one-way analysis of variance (ANOVA) was used to assess the effect of concentration on the estimated parameters. Significant differences between the control and contaminated samples were determined by the Dunnett's test. The t-test was used to determine any significant differences between the treatments.

\section{Results and discussion}

The cells of $P$. subcapitata in mid-exponential growth phase were used for tests of growth inhibition caused by the addition of different concentrations of $\mathrm{Cd}$ or $\mathrm{Cu}$. The algal biomass measured each day versus time was plotted in Figure 1 . Any addition of $\mathrm{Cd}$ led to the significant decrease of the growth of $P$. subcapitata compared with that of the control group $(p<0.05)$. The highest concentrations of $\mathrm{Cd}(100$ and $1000 \mu \mathrm{g} / \mathrm{l})$ caused the death of $P$. subcapitata cells. Even the lowest treated $\mathrm{Cd}$ concentration strongly inhibited algal biomass growth, at the last day of the experiment the $P$. subcapitata biomass in $1 \mu \mathrm{g} / \mathrm{l}$ of $\mathrm{Cd}$ was approximately by $31.2 \%$ lower than in control group. However, there were no significant differences in algal biomass at the last day cultivation of algae between the treatments with 1-2-10 $(p>0.05)$.

$\mathrm{Cu}$ toxicity was lower for $P$. subcapitata biomass than $\mathrm{Cd}$. low concentrations of $\mathrm{Cu}$ had stimulatory effect on the biomass production of P.subcapitata. There were no significant differences in the algal biomass during the 7-day cultivation of algae at the $\mathrm{Cu}$ concentrations of $1-10 \mu \mathrm{g} / \mathrm{l}$ and the control group $(p>0.05)$. At the last day of the experiment, the biggest algal biomass was found at $2 \mu \mathrm{g} / \mathrm{l}$ of $\mathrm{Cu}$, where the biomass was approximately by $77 \%$ greater than in control group.

Inhibition of algae biomass production in comparison with the control was recorded only at the highest $\mathrm{Cu}$ concentration. The biomass of P.subcapitata exposed to $100 \mu \mathrm{g} / \mathrm{l}$ of $\mathrm{Cu}$ after 7 days of treatment was by 23.9 proc. lower than that of control. The treatment with $1000 \mu \mathrm{g} / \mathrm{l}$ has led to the death of algal cell. Algal cells death treated with clinker leached solutions contained up to $796 \mathrm{mg} \mathrm{Cu} / \mathrm{L}$ was observed by Ivanova, Groudeva [34].

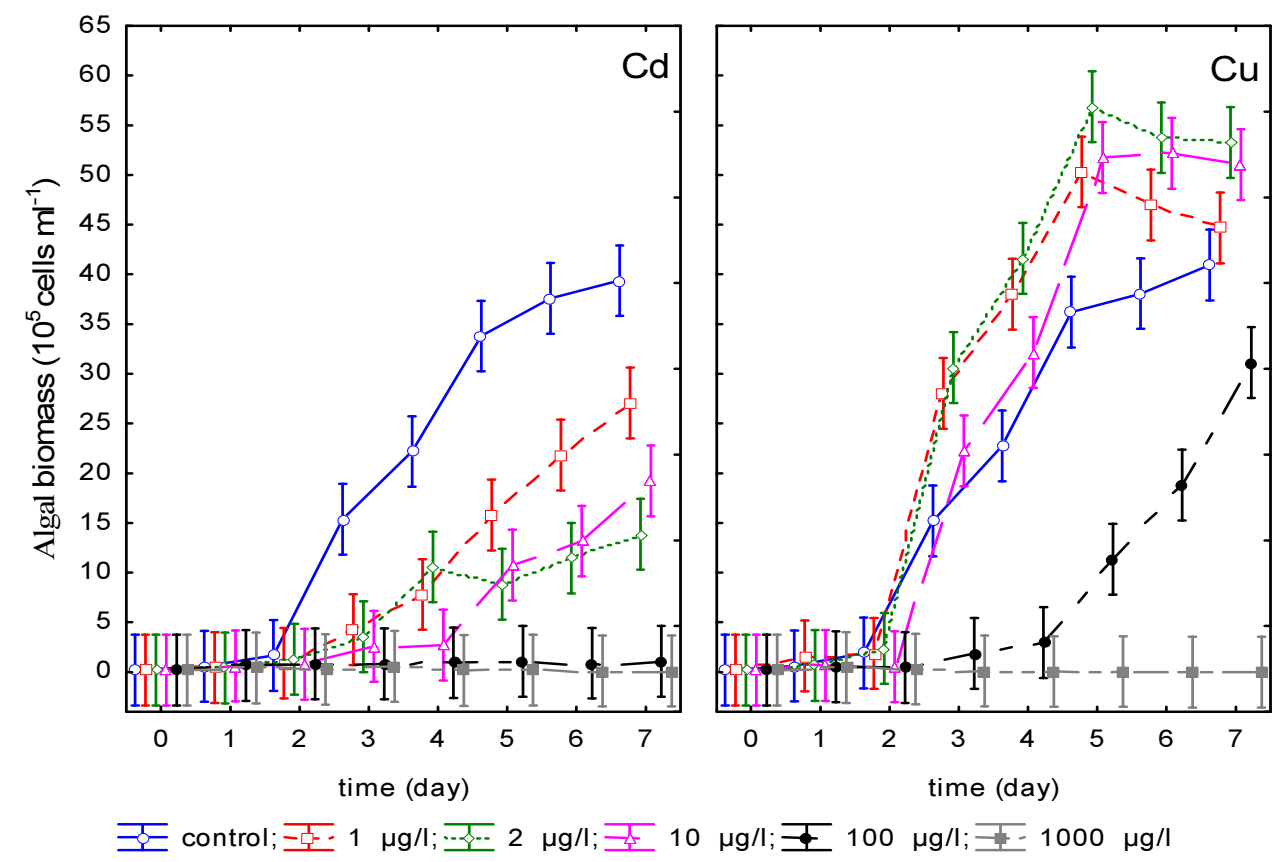

Fig. 1. Growth inhibition tests of P. subcapitata versus time (day) in algae exposed to different concentrations of cadmium and copper

The $P$. subcapitata cell growth rates $(\mu)$ after the 7-day cultures at different concentrations of $\mathrm{Cd}$ or $\mathrm{Cu}$ are shown in Figure 2. Both $\mathrm{cd}$ and $\mathrm{Cu}$ had the significant adverse effect on the P.subcapitata growth rate (ANOVA, Cd: $\mathrm{F}=73.806$, $p<0.001 ; \mathrm{Cu}: \mathrm{F}=801.24 p<0.001)$. In all tested $\mathrm{Cd}$ concentrations $P$. subcapitata growth rates were smaller than in control group, but the differences in the treatments with 1 and $10 \mu \mathrm{g} / \mathrm{l}$ of $\mathrm{Cd}$ were statistically insignificant $(p>0.05)$. Regression analysis revealed that growth rate of $P$. subcapitata significantly decreased with increasing concentration of $\mathrm{Cd}$ $\left(\mathrm{R}^{2}=0.7, p<0.001\right)$.

$\mathrm{Cu}$ had the slight stimulatory effect on the growth rate of P.subcapitata with the exception of the treatment with $1000 \mu \mathrm{g} / \mathrm{l}$ of $\mathrm{Cu}$. However the differences from the control group growth rate were statistically insignificant $(p>0.05)$. 


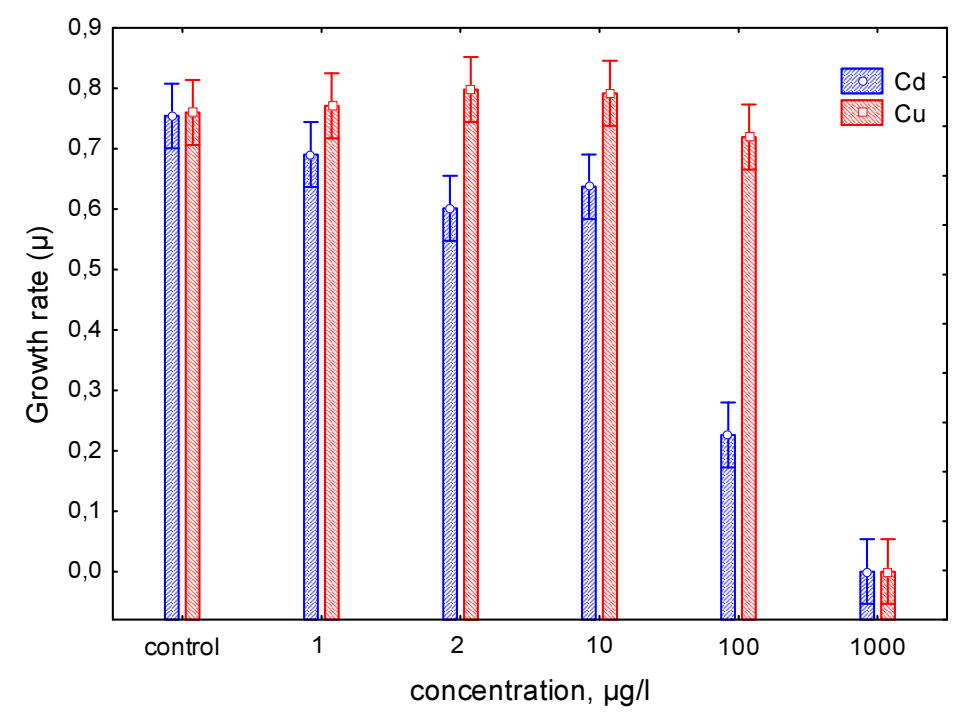

Fig. 2. Growth rates $(\mu)$ of $P$. subcapitata exposed to different concentrations of cadmium and copper for 7 days

The percent inhibition of growth rate for each treatment replicate calculated as growth \% of control is shown in Figure 3. In the lowest treated $\mathrm{Cd}$ concentration $(1 \mu \mathrm{g} / \mathrm{l}) \mathrm{P}$. subcapitata grown rate was about $31.2 \%$ smaller than in control group, while $1 \mu \mathrm{g} / \mathrm{l}$ of $\mathrm{Cu}$ has a stimulating effect, growth rate was about $9 \%$ higher than in control. All treated Cd concentrations inhibited $P$. subcapitata growth and $\mathrm{EC}_{50}$ calculated for $\mathrm{Cd}$ were found $59.24 \pm 17.53 \mu \mathrm{g} / \mathrm{l}$. Only the highest $\mathrm{Cu}$ concentration reduced $P$. subcapitata growth, while in another were stimulating effect. The highest stimulating effect in $P$. subcapitata growth treated with $\mathrm{Cu}$ were found in concentration $2 \mu \mathrm{g} / \mathrm{l}$, growth rates were about $30.2 \%$ higher than in control. As $\mathrm{Cu}$ had a stimulatory effect on the $P$. subcapitata growth, so $\mathrm{EC}_{50}$ could not be calculated.

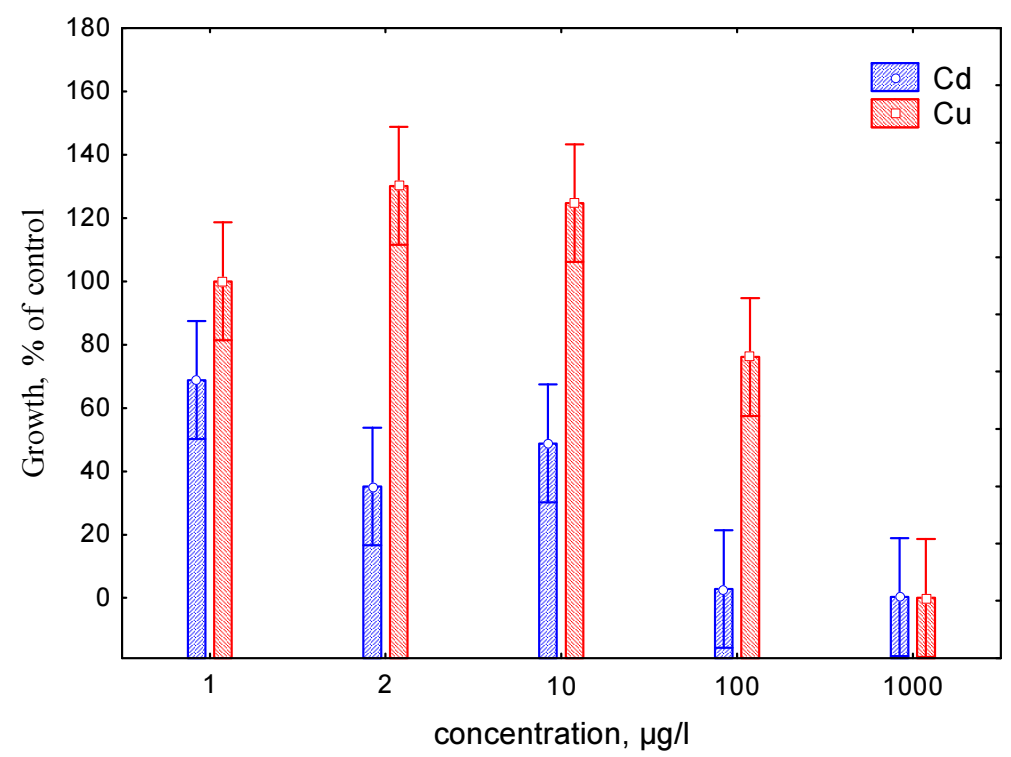

Fig. 3. P. subcapitata inhibition of growth (\% of control) exposed to different concentrations of cadmium and copper

Chlorophyll- $a$ concentrations in P. subcapitata cells at different concentrations of $\mathrm{Cd}$ or $\mathrm{Cu}$ are shown in Figure 4. All $\mathrm{Cd}$ concentrations decreased chl- $a$ concentrations in $P$. subcapitata cells, while statistically significant differences were found only in $100,1000 \mu \mathrm{g} / \mathrm{l} \mathrm{Cd}$ concentrations compared with control group $(p<0.05)$. Similarly, all Cu concentration decreased chl- $a$ content in P. subcapitata cells, while inhibitory effect was less pronounced than in Cd treatment. Statistically significant decrease of chl- $a$ concentration was observed only at the highest $\mathrm{Cu}$ concentration, when chl- $a$ concentration was by $97.9 \%$ lower than that in control algal cells. $\mathrm{EC}_{50}$, i.i. concentration causing 50 percent decrease in chl- $a$, concentrations calculated for $\mathrm{Cd}$ were found $350.5 \mu \mathrm{g} / \mathrm{l}$ and for $\mathrm{Cu}-435.2 \mu \mathrm{g} / \mathrm{l}$. Both $\mathrm{Cd}$ and $\mathrm{Cu}$ had the significant adverse effect on the chlorophyll- $a$ concentration of P.subcapitata cells (ANOVA, $\mathrm{Cd}: \mathrm{F}=10.8, \mathrm{p}<0.001 ; \mathrm{Cu}: \mathrm{F}=8.1$ $\mathrm{p}<0.001)$. 


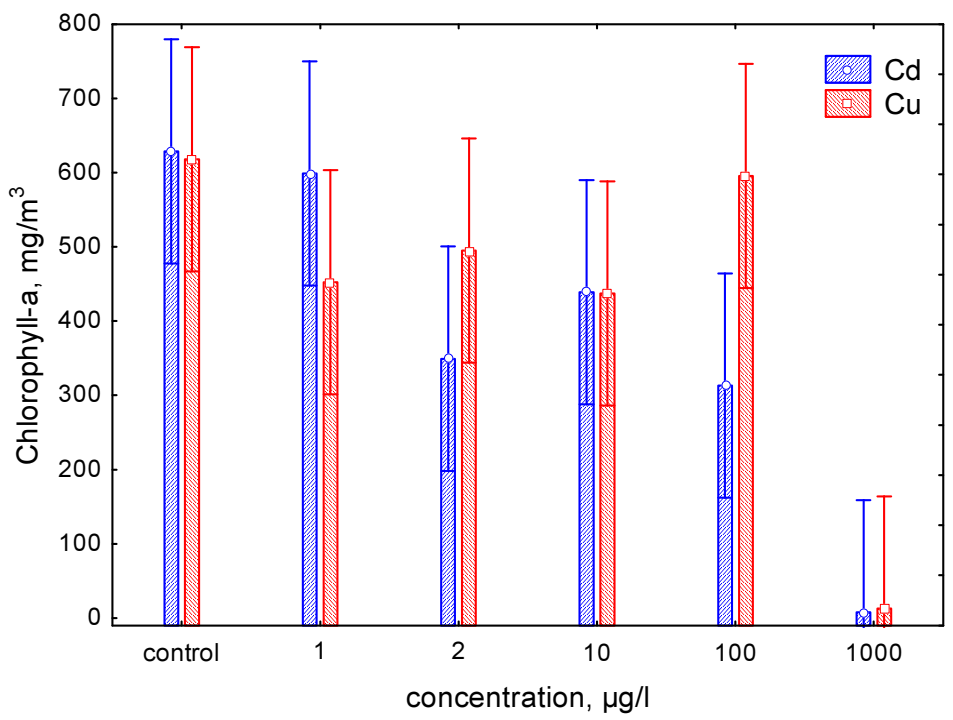

Fig. 4. Chlorophyll- $a$ concentrations in P. subcapitata exposed to different concentrations of cadmium and copper

Chlorophyll- $b$ concentrations in P. subcapitata cells at different concentrations of $\mathrm{Cd}$ and $\mathrm{Cu}$ are shown in Figure 5. Like the chl- $a$ concentrations also chl- $b$ concentrations in all treated $P$. subcapitata cells were lower than in control groups. Both treated metals had inhibitory effect on chl- $b$ concentrations in $P$. subcapitata cells. Statistically significant differences were found in 2, $1000 \mu \mathrm{g} / \mathrm{l}$ of $\mathrm{Cd}$ and $1000 \mu \mathrm{g} / \mathrm{l}$ of $\mathrm{Cu}$ concentrations compared with control groups $(p<0.05)$. Chl- $b \mathrm{EC}_{50}$ concentrations calculated for $\mathrm{Cd}$ were found $354.3 \mu \mathrm{g} / \mathrm{l}$ and for $\mathrm{Cu}-446.6 \mu \mathrm{g} / \mathrm{l}$. Both $\mathrm{Cd}$ and $\mathrm{Cu}$ had the significant adverse effect on the chlorophyll- $b$ concentration of P.subcapitata cells (ANOVA, Cd: $\mathrm{F}=10.16, p<0.001 ; \mathrm{Cu}$ : $\mathrm{F}=10.06$, $p<0.001)$.

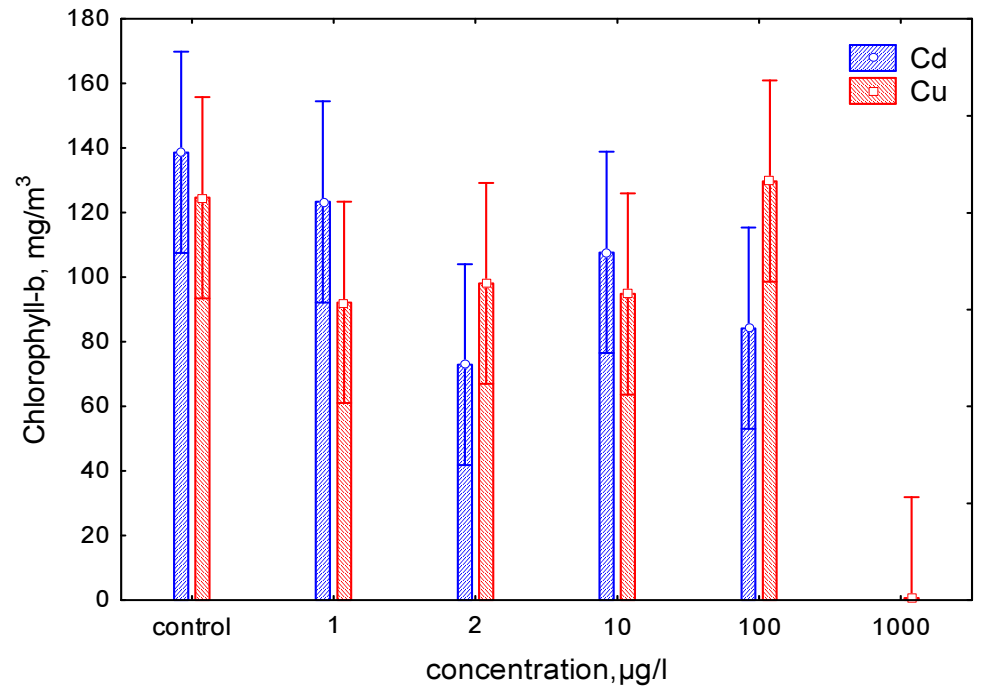

Fig. 5. Chlorophyll- $b$ concentrations in P. subcapitata exposed to different concentrations of cadmium and copper

\section{Discussion}

Investigating the effects of cadmium and copper $P$. subcapitata biomass growth over seven days, it was observed that Cd has more detrimental effect on the $P$. subcapitata biomass growth than $\mathrm{Cu}$ does. Low $\mathrm{Cu}$ concentrations stimulated the biomass growth and adverse impact on the biomass was observed only than $\mathrm{Cu}$ concentration was higher than $100 \mu \mathrm{g} / \mathrm{l}$. Both $\mathrm{Cd}$ and $\mathrm{Cu}$ at $1000 \mu \mathrm{g} / \mathrm{l}$ induced cells death.

At $2 \mu \mathrm{g} / \mathrm{l}$ of $\mathrm{Cu}$, the growth rate was by $30.2 \%$ higher than in control group, the same content of Cd decreased the growth rate $64,8 \%$ in comparison with that in control group.

Both metals decreased the content of chlorophyll- $a$ in $P$. subcapitata cells. The lowest content of chlorophyll- $a$ in the higher concentration of the metals can be due to the peroxidation of chloroplast membrane [21]. The smallest and statistically insignificant inhibition of chl- $a$ concentration was observed in $1 \mu \mathrm{g} \mathrm{Cd} / 1$ ir $100 \mu \mathrm{g} \mathrm{Cu} / \mathrm{l}$. Our results differ from those reported by Soto et al. [21], who found the stimulation of chl- $a$ at the most low concentration of copper (at $25 \mu \mathrm{g} \mathrm{Cu} / 1$ chl- $a$ concentration was more than $35 \%$ higher than in control). Photosynthetic pigments chl- $b$ concentration in algae cells in all treated $P$. subcapitata cells were smaller than in control except at $100 \mu \mathrm{g} \mathrm{Cu} / \mathrm{l}$ concentration where chl- $b$ concentration 
was by $4 \%$ higher than in control $(p>0.05)$. The highest concentration of chl- $a$ and chl- $b$ were found in treatment with $100 \mu \mathrm{g} \mathrm{Cu} / \mathrm{l}$. Our results are similar to Bossuyt and Janssen [35], who found a significant increase in chl- $a$ at higher concentrations of metals in P. subcapitata. The lowest inhibition of chl- $b$ concentration in $P$. subcapitata treated with Cd, was observed in $1 \mu \mathrm{g} / \mathrm{l}$ concentration, while no statistically significant differences were found with control group.

Calculated $\mathrm{EC}_{50}$ for growth rate for $\mathrm{Cd}$ was $59.24 \pm 17.53 \mu \mathrm{g} / \mathrm{l}$, for chl- $a$ content $-350.52 \mu \mathrm{g} \mathrm{Cd} / 1$ and on chl- $b-$ $354.34 \mu \mathrm{g} \mathrm{Cd} / 1$. The other researchers calculated lower effective concentrations for P. subcapitata (Selenastrum capricornutum) growth for $72 \mathrm{~h}$, Kaneko et al. [36] $\mathrm{EC}_{50}-190 \mu \mathrm{g} \mathrm{Cd} / \mathrm{l}$, Källqvist [15] - $9.4 \mu \mathrm{g} \mathrm{Cd} / \mathrm{l}$. The differences may be due to the chemical characteristics of test water, such as $\mathrm{pH}$, hardness, time exposure, concentration and type of chelating agent in the nutrients used in the these studies. On the other hand, the differences in the effects of the metals could be attributed to the redox potential of the metals [20]. As $\mathrm{Cu}$ had a stimulatory effect on the Pseudokirchneriella subcapitata growth rate, so $\mathrm{EC}_{50}$ could not be calculated. $\mathrm{EC}_{50}$ value was calculated for inhibition of chl- $a$ and chl- $b$ content, $435.23 \mu \mathrm{g}$ $\mathrm{Cu} / 1$, and $-446.56 \mu \mathrm{g} \mathrm{Cu} / 1$, respectively. These values are much higher than those reported by other workers. The toxicity of copper to $P$. subcapitata has been reported by a number of workers $[15,21,29,34-35,37-38]$. EC 50 values range from 8 to $400 \mu \mathrm{g} \mathrm{Cu} / \mathrm{l}$. It has been suggested that the main reason for this high variability is attributable to the differences in culture and test media composition affecting both the algal performance and the metal's bioavailability [35, 39].

\section{Conclusion}

Our study showed that toxicity of $\mathrm{Cd}$ was higher than $\mathrm{Cu}$ to green algae Pseudokirchneriella subcapitata growth and chlorophyll content. $\mathrm{Cu}$ has stimulated Pseudokirchneriella subcapitata growh, while all treated concentrations of Cd inhibited Pseudokirchneriella subcapitata growth.

We found that photosynthetic pigments (chlorophyll- $a$ and chlorophyll- $b$ concentration) were less sensitive to metals than the growth rate. The growth rate of Pseudokirchneriella subcapitata decreased with increasing concentration of metals ions. Cadmium and copper significantly reduced the concentrations of chlorophyll- $a$ and chlorophyll- $b$ in algae cells.

The results of our study show that algae may be severely affected by the heavy metals even at environment relevant concentrations.

\section{References}

[1] Flouty, R.; Estephane, G. 2012. Bioaccumulation and biosorption of copper and lead by a unicellular algae Chlamydomonas reinhardtii in single and binary metal systems: a comparative study, Journal of Environmental Management 111: 106-114. http://dx.doi.org/10.1016/j.jenvman.2012.06.042

[2] Franklin, N. M.; Stauber, J.L.; Apte, S.C.; Lim, R.P. 2002. Effect of initial cell density of the bioavailability and toxicity of copper in microalgal bioassays, Environmental Toxicology and Chemistry 21: 742-751. http://dx.doi.org/10.1002/etc.5620210409

[3] Koutsaftis A.; Aoyama I. 2006. The Interactive Effects of Binary Mixtures of Three Antifouling Biocides and Three Heavy Metals Against the Marine Algae Chaetoceros gracilis, Environmental Toxicology 21(4): 432-439. http://dx.doi.org/10.1002/tox.20202

[4] Inze, D.; Gutierrez, C.; Chua, N-H. 1999. Trends in plant cell cycle research, Plant Cell 11: 991-994. http://dx.doi.org/10.1105/tpc.11.6.991

[5] Montvydienè, D.; Marčiulionienè, D. 2004. Assessment of toxic interactions of heavy metals in a multicomponents mixture using Lepidium sativum and Spirodela polyrrhiza, Environmental Toxicology 19(4): 351-358. http://dx.doi.org/10.1002/tox.20041

[6] Qian, H.F; Chen, W.; Li, J.J.; Wang, J.; Zhou, Z.; Liu, W.P.; Fu, Z.G. 2009. The effect of exogenous nitric oxide on alleviating herbicide damage in Chlorella vulgaris, Aquatic Toxicology 92: 250-257. http://dx.doi.org/10.1016/j.aquatox.2009.02.008

[7] Playle, R. C. 2004. Using multiple metal-gill binding models and the toxic unit concept to help reconcile multiple-metal toxicity results, Aquatic Toxicology 67: 359-370. http://dx.doi.org/10.1016/j.aquatox.2004.01.017

[8] Araujo, R. P. A.; Botta-Passchoal, C. M. R.; Silverio, P. F.; Almeida, R.V.; Rodriguês, P. E.; Umbezeiro, R. E.; Umbezeiro, G. A. 2006. Application of toxicity identification evaluation to sediment in a highly contaminated water reservoir in southeastern Brazil, Environmental Toxicology and Chemistry 25(2): 581-588. http://dx.doi.org/10.1897/05-144R.1

[9] Vandenbrouck, T.; Soetaert, A.; Ven, K.; Blust, R.; De Coen, W. 2009. Nickel and binary metal mixture responses in Daphnia magna: Molecular fingerprints and (sub)organismal effects, Aquatic Toxicology 92: 18-29. http://dx.doi.org/10.1016/j.aquatox.2008.12.012

[10] Ishido, M.; Homma-Takeda, S.; Tohyama, C.; Suzuki, T. 1998. Apoptosis in rat renal proximal tubular cells induced by cadmium, Journal of Toxicology and Environmental Health 55(1): 1-12. http://dx.doi.org/10.1080/009841098158584

[11] Hagopian-Schlekat, T.; Chandler, G. T.; Shaw, T. J. 2001. Acute toxicity of five sediment-associated metals, individually and in a mixture, to the estuarine meiobenthic harpacticoid copepod Amphiascus tenuiremis, Marine Environmental Research 51: $247-264$. http://dx.doi.org/10.1016/S0141-1136(00)00102-1

[12] Cooper, N. L.; Bidwell, J. R.; Kumar, A. 2009. Toxicity of copper, lead,and zinc mixtures to Ceriodaphnia dubia and Daphnia carinata, Ecotoxicology and Environmental Safety 72: 1523-1528. http://dx.doi.org/10.1016/j.ecoenv.2009.03.002

[13] Jamers, A.; Blusta, R.; De Coena, W.; Griffinb, J. L.; Jonesc, O.A.H. 2013. An omics based assessment of cadmium toxicity in the green alga Chlamydomonas reinhardtii, Aquatic Toxicology 126: 355-364. http://dx.doi.org/10.1016/j.aquatox.2012.09.007

[14] Balen, B; Tkalec, M; Sikić, S; Tolić, S; Cvjetko, P; Pavlica, M; Vidaković-Cifrek, Z. 2011. Biochemical responses of Lemna minor experimentally exposed to cadmium and zinc, Ecotoxicology 20: 815-826. http://dx.doi.org/10.1007/s10646-011-0633-1

[15] Källqvist, T. 2009 .Effect of Water Hardness on the Toxicity of Cadmium to the Green Alga Pseudokirchneriella subcapitata in an Artificial Growth Medium and Nutrient-Spiked Natural Lake Waters, Journal of Toxicology and Environmental Health, Part A 72: $277-283$.

[16] Ngo, H. T. T.; Gerstmann, S.; Frank, H. 2009.Toxicity of cadmium to the green alga Parachlorella kessleri: Producing Cd-loaded algae for feeding experiments, Toxicological and Environmental Chemistry 91(2): 279-288

[17] Wang, M.-J.; Wang, W.-X. 2009. Cadmium in three marine phytoplankton: Accumulation, subcellular fate and thiol induction, Aquatic Toxicology 95 99-107.

[18] Jamers, A.; Lenjou, M.; Deraedt, P.; Van Bockstaele, D.; Blust, R.; De Coen, W. 2009. Flow cytometric analysis of the cadmium-exposed green alga Chlamydomonas reinhardtii (Chlorophyceae), European Journal of Phycology 44(4): 541-550.

[19] Moreno, M. D. 2003. Toxicología ambiental. Evaluación del riesgo para la salud humana. Ed. McGraw-Hill, Madrid. pp. 384. 
[20] Srivastava, S. S.; Mishra, R. D.; Tripathi, S.; Dwivedi, D.; Gupta, K. 2006. Copper-induced oxidative stress and responses of antioxidants and phytochelatins in Hydrilla certicillata (L.F.) Royle, Aquatic Toxicology 80: 405-415. http://dx.doi.org/10.1016/j.aquatox.2006.10.006

[21] Soto, P.; Gaete, H.; Hidalgo, M. E. 2011. Assessment of catalase activity, lipid peroxidation, chlorophyll- $a$, and growth rate in the freshwater green algae Pseudokirchneriella subcapitata exposed to copper and zinc, Latin American Journal of Aquatic Research 39(2): 280-285. http://dx.doi.org/10.3856/vol39-issue2-fulltext-9

[22] Kanoun-Boulé, M.; Vicentea, J.A.F.; Nabaisa ,C.; Prasad, M.N.V.; Freitas, F. 2009. Ecophysiological tolerance of duckweeds exposed to copper, Aquatic Toxicology 91(1): 1-9. http://dx.doi.org/10.1016/j.aquatox.2008.09.009

[23] International Organization for Standardization. 1987. Water quality—Algal growth inhibition test. Draft International Standard ISO/DIS 8692. Geneva, Switzerland.

[24] Organization for Economic Cooperation and Development. 1984.Guideline for testing chemicals. No. 201. Algae growth inhibition test. Paris, France.

[25] USEPA.1985. Freshwater algae acute toxicity test. Fed. Reg., 50, 39,323-39, 333.

[26] Lewis, M .A. 1995. Algae and vascular plant tests. In: Rand, G.M. (Ed.), Fundamentals of Aquatic Toxicology: Effects, Environmental Fate, and Risk Assessment. Taylor and Francis, Washington, DC, pp. 135-169.

[27] Blaise, C. 1991. Microbiotests in aquatic ecotoxicology: characteristics, utility and prospects, Environmental Toxicology Water Quality 6: 145-155. http://dx.doi.org/10.1002/tox.2530060204

[28] Rojy'ckova, R.; Dvorakova, D.; Marsalek, B. 1998. The use ofminiaturized algal bioassays in comparison to the Standard flask assay, Environmental Toxicology. Water Quality 13: 235-241.

[29] Koukal, B.; Rossé, P.; Reinhardt, A.; Ferrari, B.; Wilkinson, K. J.; Loizeau, J. L.; Dominik, J. 2007. Effect of Pseudokirchneriella subcapitata (Chlorophyceae) exudates on metal toxicity and colloid aggregation, Water Research 41: 63-70. http://dx.doi.org/10.1016/j.watres.2006.09.014

[30] Organization for Economic Cooperation and Development. 202.Guideline for testing chemicals. No. 201. Algae growth inhibition test. Paris, France

[31] ISO. 2004. ISO 8692-Water quality. Algal growth inhibition test with unicellular green algae. Geneva, Switzerland: International Organisation for Standardisation.

[32] Organisation for Economic Co-operation and Development, 1996. OECD guidelines for testing of chemicals. Publication Service OECD, Paris, France.

[33] ASTM. 1993. Standard practices for measurement of chlorophyll content of algae in surface waters, D 3731-87. ASTM Standards on Aquatic Toxicology and Hazard Evaluation, 2-5.

[34] Ivanova, I.; Groudeva, V. 2006. Use of Selenastrum capricornutum growth inhibition test for testing toxicity of metal ions in soil and water, Biotechnology and Biotechnological Equipment 20(1): 179-183.

[35] Bossuyt, B.; Janseen, C. 2004. Long-term acclimation of Pseudokirchneriella subcapitata (Korshikov) Hidak to different copper concentrations; change in tolerante and physiology, Aquatic Toxicology 68: 61-74. http://dx.doi.org/10.1016/j. aquatox.2004.02.005

[36] Kaneko, H.; Shimada, A.; Hirayama, K. 2004. Shortterm algal toxicity test based on phosphate uptake, Water Research 38: $2173-2177$. http://dx.doi.org/10.1016/j.watres.2004.02.006

[37] Lukavský, J.; Furnadjieva, S.; Cepák, V. 2003. Toxicity of metals, $\mathrm{Al}, \mathrm{Cd}, \mathrm{Co}, \mathrm{Cr}, \mathrm{Cu}, \mathrm{Fe}, \mathrm{Ni}, \mathrm{Pb}$ and $\mathrm{Zn}$ on microalgae, using microplate bioassay 1 : Chlorella kessleri, Scenedesmus quadricauda, Sc. subspicatus and Raphidocelis subcapitata (Selenastrum capricornutum), Algological Studies 110(1): 127-141. http://dx.doi.org/10.1127/1864-1318/2003/0110-0127

[38] Michnowicz, C. J.; Weaks, T. E. 1984. Effects of pH on toxicity of As, Cr, Cu, Ni and Zn to Selenastrum capricornutum Printz., Hydrobiologia 118 299-305. http://dx.doi.org/10.1007/BF00046627

[39] Janssen, C. R.; Heijrick, D. G. 2003. Algal toxicity testing for environmental risk assessment of metals: physiological and ecological considerations, Reviews of Environmental Contamination and Toxicology 178: 23-52. http://dx.doi.org/10.1007/0-387-21728-2_2 